\title{
Genome-Enhanced Detection and Identification (GEDI) of plant pathogens
}

\author{
Nicolas Feau ${ }^{1}$, Stephanie Beauseigle ${ }^{2}$, Marie-Josée Bergeron ${ }^{3}$ ， Guillaume J Bilodeau ${ }^{4}$, Inanc Birol ${ }^{5}$, \\ Sandra Cervantes-Arango ${ }^{1}$, Braham Dhillon ${ }^{6}$, Angela L Dale ${ }^{1,7}$, Padmini Herath ${ }^{1}$, Steven JM Jones ${ }^{5,8,9}$, \\ Josyanne Lamarche ${ }^{3}$, Dario I Ojeda ${ }^{10}$, Monique L Sakalidis ${ }^{11}$ ， Greg Taylor ${ }^{5}$, Clement KM Tsui ${ }^{12}$, Adnan \\ Uzunovic $^{7}$, Hesther Yueh ${ }^{1}$, Philippe Tanguay ${ }^{3}$, Richard C Hamelin ${ }^{\text {Corresp. }{ }^{1,13}}$ \\ 1 Department of Forest and Conservation Sciences, Forest Sciences Centre, University of British Columbia, Vancouver, BC, Canada \\ 2 Biopterre, Sainte-Anne-de-la-Pocatière, Quebec, Canada \\ 3 Canadian Forest Service, Natural Resources Canada, Quebec city, Quebec, Canada \\ 4 Ottawa Plant Laboratory, Canadian Food Inspection Agency, Ottawa, Ontario, Canada \\ 5 BC Cancer agency, Genome Sciences Centre, Vancouver, BC, Canada \\ 6 Department of Plant Pathology, University of Arkansas at Fayetteville, Fayetteville, Arkansas, United States \\ 7 FPInnovations, Vancouver, BC, Canada \\ 8 Department of Medical Genetics, University of British Columbia, Vancouver, BC, Canada \\ 9 Department of Molecular Biology and Biochemistry, Simon Fraser University, Burnaby, BC, Canada \\ 10 Department of Biology Unit of Ecology and Genetics, University of Oulu, Oulu, Finland \\ 11 Department of Plant, Soil \& Microbial Sciences and Department of Forestry, Michigan State University, East Lansing, Michigan, United States \\ 12 Faculty of Medicine, University of British Columbia, Vancouver, BC, Canada \\ 13 Foresterie et géomatique, Institut de Biologie Intégrative des Systèmes, Laval University, Quebec city, Quebec, Canada \\ Corresponding Author: Richard C Hamelin \\ Email address: richard.hamelin@ubc.ca
}

Plant diseases caused by fungi and Oomycetes represent worldwide threats to crops and forest ecosystems. Effective prevention and appropriate management of emerging diseases rely on rapid detection and identification of the causal pathogens. The increase in genomic resources makes it possible to generate novel genome-enhanced DNA detection assays that can exploit whole genomes to discover candidate genes for pathogen detection. A pipeline was developed to identify genome regions that discriminate taxa or groups of taxa and can be converted into PCR assays. The modular pipeline is comprised of four components: 1) selection and genome sequencing of phylogenetically related taxa, 2 ) identification of clusters of orthologous genes, 3 ) elimination of false positives by filtering, and 4) assay design. This pipeline was applied to some of the most important plant pathogens across three broad taxonomic groups: Phytophthoras (Stramenopiles, Oomycota), Dothideomycetes (Fungi, Ascomycota) and Pucciniales (Fungi, Basidiomycota). Comparison of 73 fungal and Oomycete genomes led the discovery of 5939 gene clusters that were unique to the targeted taxa and an additional 535 that were common at higher taxonomic levels. Approximately $28 \%$ of the 299 tested were converted into qPCR assays that met our set of specificity criteria. This work demonstrates that a genome-wide 
approach can efficiently identify multiple taxon-specific genome regions that can be converted into highly specific PCR assays. The possibility to easily obtain multiple alternative regions to design highly specific qPCR assays should be of great help in tackling challenging cases for which higher taxon-resolution is needed. 
1

\section{Genome-Enhanced Detection and Identification}

\section{(GEDI) of plant pathogens}

4 Nicolas Feau ${ }^{1}$, Stéphanie Beauseigle ${ }^{2}$, Marie-Josée Bergeron ${ }^{3}$, Guillaume J. Bilodeau ${ }^{4}$, Inanç

5 Birol $^{5}$, Sandra Cervantes-Arango ${ }^{1}$, Braham Dhillon ${ }^{6}$, Angela L. Dale ${ }^{1,7}$, Padmini Herath ${ }^{1}$, Steven

6 J.M. Jones ${ }^{5,8,9}$, Josyanne Lamarche ${ }^{3}$, Dario I. Ojeda ${ }^{10}$, Monique L. Sakalidis ${ }^{11}$, Greg Taylor ${ }^{5}$,

7 Clement Tsui ${ }^{12}$, Adnan Uzunovic ${ }^{7}$, Hesther Yueh ${ }^{1}$, Philippe Tanguay ${ }^{3}$ and Richard C.

8 Hamelin $^{1,13}$

9

${ }^{1}$ Department of Forest and Conservation Sciences, Forest Sciences Centre, University of British Columbia, Vancouver, BC, Canada

${ }^{2}$ Biopterre, Sainte-Anne-de-la-Pocatière, Quebec, Canada

${ }^{3}$ Canadian Forest Service, Natural Resources Canada, Québec, QC, Canada

${ }^{4}$ Ottawa Plant Laboratory, Canadian Food Inspection Agency, Ottawa, ON, Canada

${ }^{5}$ British Columbia Cancer Agency, Genome Sciences Centre, Vancouver, BC, Canada

${ }^{6}$ Department of Plant Pathology, University of Arkansas at Fayetteville, Fayetteville, Arkansas, United States

${ }^{7}$ FPInnovations, Vancouver, BC, Canada

${ }^{8}$ Department of Medical Genetics, University of British Columbia, Vancouver, BC, Canada

${ }^{9}$ Department of Molecular Biology and Biochemistry, Simon Fraser University, Vancouver, BC, Canada

${ }^{10}$ Department of Biology Unit of Ecology and Genetics, University of Oulu, Oulu, Finland 
${ }^{11}$ Department of Plant, Soil \& Microbial Sciences and Department of Forestry, Michigan State 26 University, East Lansing, MI, USA.

$27{ }^{12}$ Faculty of Medicine, University of British Columbia, Vancouver, BC, Canada 28

$29{ }^{13}$ Foresterie et géomatique, Institut de Biologie Intégrative des Systèmes, Université Laval, 30 Québec, QC, Canada 


\section{Abstract}

Plant diseases caused by fungi and Oomycetes represent worldwide threats to crops and

forest ecosystems. Effective prevention and appropriate management of emerging diseases rely on rapid detection and identification of the causal pathogens. The increase in genomic resources makes it possible to generate novel genome-enhanced DNA detection assays that can exploit whole genomes to discover candidate genes for pathogen detection. A pipeline was developed to identify genome regions that discriminate taxa or groups of taxa and can be converted into PCR assays. The modular pipeline is comprised of four components: 1) selection and genome sequencing of phylogenetically related taxa, 2) identification of clusters of orthologous genes, 3) elimination of false positives by filtering, and 4) assay design. This pipeline was applied to some of the most important plant pathogens across three broad taxonomic groups: Phytophthoras (Stramenopiles, Oomycota), Dothideomycetes (Fungi, Ascomycota) and Pucciniales (Fungi, Basidiomycota). Comparison of 73 fungal and Oomycete genomes led the discovery of 5939 gene clusters that were unique to the targeted taxa and an additional 535 that were common at higher taxonomic levels. Approximately $28 \%$ of the 299 tested were converted into qPCR assays that met our set of specificity criteria. This work demonstrates that a genome-wide approach can efficiently identify multiple taxon-specific genome regions that can be converted into highly specific PCR assays. The possibility to easily obtain multiple alternative regions to design highly specific qPCR assays should be of great help in tackling challenging cases for which higher taxon-resolution is needed. 

forest ecosystems. The inadequacy of disease diagnostics, reporting protocols and the lack of

60

61

62

centralized recording mechanisms have been identified as causes for the increase in emerging diseases of plants and animals (Fisher et al., 2012). To prevent and manage those emerging diseases, rapid detection and identification of the causal pathogens are crucial. This is particularly important for tree diseases where large contiguous forest ecosystems can be threatened by invasive and emerging pathogens, resulting in ecosystem-wide irreversible damage when prevention and management fail (Pautasso et al., 2015). Plant pathogens can be transmitted by a variety of means, including natural dispersal in water, rain and wind. But because of their cryptic nature and their ability to remain dormant in plants or soil, introduction and spread of alien invasive species are often related to anthropogenic activities. The intensification of drivers such as international trade, combined with climate change contribute to the emergence and rapid increase of the threat that plant pathogens may cause to ecosystems (Desprez-Lousteau et al., 2016; Pautasso et al., 2015; Santini et al., 2013).

DNA detection methods have provided powerful tools with broad applications for the detection and monitoring of invasive species. However, DNA-based assay design for plant pathogen detection relies mostly on the amplification and detection of a very small fraction of the target organism's genome. Assays are generally designed to amplify between one and three genes or genome regions that are conserved in all eukaryotes such as the internal transcribed spacer region (ITS rDNA), intergenic spacer region (IGS) and beta-tubulin (BT) (Schena et al., 2013). Single nucleotide polymorphisms (SNPs) in these conserved regions are sometimes abundant enough to design primers and/or probes that are specific to a targeted taxon and can discriminate closely related species (Prévost-Bouré et al., 2011; Thonar et al., 2012; Schena et 
81 al., 2013). However, this method has limitations when applied to taxa that diverged recently

82 since they often share highly homologous or even identical sequences in these conserved gene

83 regions. This limits assay design and increases the risk of false positive results by making it

84 difficult to find discriminant SNPs. This could be critical in cases where closely related

85 microorganisms pose different risks and lead to different epidemiological or regulatory

86 outcomes.

87

88

89

90

91

92

93

94

95

96

97

98

99

100

101

102

103

Genomics can play a valuable role in the discovery and characterization of emerging pathogens (Firth et al., 2013). The increase in genomic resources brought by next generation sequencing opens the way to mining entire genomes of pathogens and their close relatives to identify genes or genomic regions that are unique to a taxon or to a group of taxa. This is promising and has been used to design assays for a wide range of microbe-host combinations. Applications include detecting genetic material shed by invasive fish in environmental (eDNA) water samples (Farrington et al., 2015), human infecting bacteria (Ho et al., 2011; 2012; Hung et al., 2012), zoonotic infectious bacteria (Hänsel et al., 2015; Blaecher et al., 2016) and plant pathogenic bacteria (Pritchard et al., 2012).

Herein, we describe a pipeline to compare whole genomes of plant pathogens and

97 phylogenetically related taxa to identify genome regions specific to targeted taxa or groups of 98 related taxa and design highly accurate PCR assays. As a proof-of-concept, we have applied our assay development pipeline to a range of taxonomically diverse plant pathogens to demonstrate that it is robust, flexible and broadly applicable. Our method allowed for the rapid and efficient discovery of genome regions that provide highly specific targets for the development of assays to detect some of the most damaging plant pathogens across three broad taxonomic groups: Phytophthora (Heterokonts, Oomycota), Dothideomycetes (Fungi, Ascomycota) and Pucciniales 
104 (Fungi, Basidiomycota). This pipeline can be applied to a broad range of organisms, including 105 pathogens of crops, forest trees and animals for which genomic resources are available.

Materials and methods

Pipeline development

Our approach required access to assembled and annotated genomes of the targeted organisms as well as closely related taxa. The underlying principle of our method is to compare the protein content within the genomes of phylogenetically related taxa to ensure the selection of targets that are discriminant towards the most closely related known species. Our bioinformatics pipeline is protein models predicted from a whole genome sequence) are selected for the targeted species under investigation and for a group of related species. In the second module, clusters of homologous genes are generated from the protein sets of all available genomes to identify candidate protein clusters that are unique to the targeted species. The third module is a filtering step aimed at eliminating false positive candidates generated in the previous step. The fourth module consists of automated primer and probe design for the candidate genes retained in module 3 . The four modules are detailed below and the pipeline is applied to plant pathogens.

\section{Module 1: Genomic resources}

123 In order to maximize the accurate identification of candidate protein clusters that are unique to 124 the targeted taxa and contain enough polymorphisms for the design of species-specific or group125 specific qPCR assays, genomes of target and related non-target taxa are required (e.g. same genus and order). To achieve this, de novo genome assemblies and full protein sets are either 
127 produced and assembled for the targeted species under investigation and for a group of related

128 species or recovered from public genome data repositories. Next-generation sequencing (NGS)

129 techniques constitute a fast and cost-effective way of obtaining whole genome sequences,

130 particularly in eukaryotic organisms with small genomes such as pathogenic fungi (Faino and

131 Bart, 2014). De novo genome assemblies can quickly be achieved with assemblers such as

132 ABySS (Simpson et al., 2009; Gallo et al., 2014; Abbas et al., 2014) (see below:

133 Computational testing and experimental screening); then, AUGUSTUS (Stanke et al., 2006) can

134 provide a fast way to generate $a b$ initio gene/protein model prediction (i.e. the "gene space")

135 from these de novo assemblies (Li-Jun et al., 2010; Haas et al., 2011; Faino and Bart, 2014). In

136 addition, a collection of genomes of target and non-target taxa can be obtained through the

137 publicly available fungal genome sequencing initiatives such as the Mycocosm (Grigoriev et al.,

138 2014) and the 1000 Fungal Genomes project (http://1000.fungalgenomes.org/home/). Currently,

139 more than 2,100 de novo fungal genome assemblies are available in the NCBI database,

140 representing about one thousand fungal species distributed along all the branches of the fungal

141 tree of life (Figure 2).

142 Module 2: Discovering homologous gene clusters

143 OrthoMCL (Li et al., 2003) is used to generate clusters of homologous genes (orthologs and

144 paralogs) using the protein sets of all genomes previously selected. This allows for identification

145 of candidate protein clusters that are unique to a taxon or that are common to members of a

146 group and absent in the other taxa ("higher hierarchical levels"). Briefly, the OrthoMCL

147 procedure comprises an all-against-all BLASTp step with a similarity cutoff defined by an e-

148 value of 1e-20 and minimum overlap of 50\% followed by a Markov clustering (MCL) of groups

149 of homologs. Cluster tightness is regulated by an inflation parameter arbitrarily selected between 
150 values of 1.1 (fewer clusters with more proteins in each) to 5.0 (smaller clusters of proteins with

151 high similarity); by default, we used $\mathrm{I}=1.5$ to try to cluster together as many homologous

152 proteins with relatively high similarity. Following MCL clustering the output file is parsed to

153 identify candidate clusters. These can be taxa-specific clusters containing one or several proteins

154 unique to a single taxon or higher level hierarchical clusters containing at least one protein

155 homolog for each taxon in a group (e.g. multiples species within a clade); cDNA sequences are

156 then retrieved from each candidate protein cluster, aligned using MUSCLE (Edgar, 2004) and

157 stored in a fasta format until further processing.

158 Module 3: Filtering false positives

159 This filtering step is crucial to account for putative unique genes that are present in other

160 genomes but were mis-annotated and/or fragmented. Gene fragments may be caused by

161 truncation of the protein-coding sequence in the genome due to the termination of a contig in the

162 middle of an open reading frame. Such fragments may result in OrthoMCL clustering errors by

163 clustering them in groups that are distinct from the group containing their true full-length

164 homologs. Thus, to ensure that candidate clusters were truly unique, i.e. specific to the target

165 genome, BLASTn and BLASTp searches were conducted using candidate proteins and cDNA

166 sequences retrieved in Module 2 against all non-target genomes and protein sets, respectively

167 (Figure 1). The BLASTn search minimizes the likelihood of obtaining a candidate cluster that

168 would result from an annotation error in the target genome or due to gene mispredictions in the

169 non-target genomes. The BLASTp search aims to minimize the effect of truncated protein

170 models (Text S1).

171 The e-value cutoff for BLASTp and BLASTn searches must be selected based on the

172 level of identity between the genomes of target and non-target taxa, the estimated number of 
173 candidates, the quality of the genomes and the tolerance of potential false positives. Filtering

174 simulations (see Results section "Computational testing”) helped to identify default parameters

175 with "stringent" cutoff threshold values set at 1e-20 for both BLASTn and BLASTp to retain a

176 minimum of candidate clusters.

177 Module 4: Assay design

178 The final module implements the assay design, using PRIMER3 (Rozen and Skaletsky 1999) to

179 generate unique or common primers and probes for PCR or qPCR assays. For each candidate

180 gene, a primer pair and a probe are automatically designed from the cDNA alignment with

181 PRIMER3 parameters as described in Table 1.

182

\section{Computational testing and experimental screening}

184 Testing the cutoff filters. False positive filtering with BLASTn and BLASTp (Module 3) was

185 first tested with a set of 11 Phytophthora genomes and subsequently using a second set of 16

186 Dothideomycetes genomes. For each dataset, Module 2 was run with default parameters. Then,

187 filtering simulations with different BLASTn and BLASTp cutoff values were carried out as

188 described in Text S1 ("Filtering simulations with Module 3").

189 Pipeline runs. We assessed the robustness of this pipeline by testing it in three divergent

190 taxonomic groups. The genomes of 19 tree pathogens belonging to the genus Phytophthora, the

191 class Dothideomycetes or the order Uredinales were sequenced, assembled and annotated (Table

192 S1-S3). Paired-end Illumina sequencing, read filtering and assembly procedures were described

193 in Lamarche et al. (2015) and Feau et al. (2016). Ab initio gene and protein model predictions

194 were obtained by using AUGUSTUS trained with i) de novo transcriptome assemblies obtained

195 using trans-ABySS for the corresponding species of Phytophthora and Dothideomycetes (Text 
196 S1 "RNA-seq libraries") or ii) gene and protein sets from closely related species for the

197 Pucciniales. From each of these three genome collections, a subset was selected, which included

198 the targeted species and other species in the same taxonomic group. This subset was then

199 enriched with publicly available genomes from additional phylogenetically related species.

200 We tested the pipeline on the invasive species Phytophthora ramorum responsible for the

201 sudden oak death and sudden larch death diseases, P. lateralis a pathogen of Port Orford Cedar

202 (Chamaecyparis lawsoniana) and P. kernoviae a pathogen of european beech (Hansen et al.,

203 2000; Brasier et al., 2005, Brasier and Webber 2010). In order to perform genome comparison to

204 identify unique genome regions, we obtained the genomes of eight non-target taxa from

205 phylogenetic clades 1, 2, 7, 8 and 10 (as defined in Martin et al., 2014) (Table S3). In the

206 Dothideomycetes, we obtained the genomes of 39 Dothideomycetes (mostly in the Capnodiales

207 and one Pleosporales; Table S1) and searched for candidate genes in two poplar pathogens

208 causing cankers (Sphaerulina musiva) and leaf spots (S. populicola; Dhillon et al., 2015) and in

209 Phaeocryptopus gaeumannii, the causal agent of the Swiss needle cast of Douglas fir.

210 For the rust fungi, we obtained the genome sequences of 17 Pucciniales, including

211 members of the genera Melampsora, Cronartium, Endocronartium, Puccinia, Mixia,

212 Sporobolomyces and Rhodotorula (Table S2). We searched these genomes for candidate genes in

213 three rusts attacking poplars and pines: the European (Melampsora larici-populina) and North

214 American (M. medusae f. sp. deltoidae) poplar rust and the white pine blister rust (Cronartium

215 ribicola).

216 In silico screening for intra-taxon variation. We assessed the possibility that some of the

217 candidate genes obtained in Module 3 may fail to generate the expected amplicon in all the

218 individuals within the targeted taxa due to intra-taxa variability and presence/absence 
219 polymorphisms. BLASTn searches (e-value cutoff of 1e-20) were conducted using the candidate

220 genes obtained for $P$. ramorum after Module 3 filtering against 40 P. ramorum de novo genome

221 assemblies (Dale et al. submitted). Similarly, candidate genes targeting S. musiva were searched

222 against 16 de novo genome assemblies obtained for this species (Sakaladis et al. in prep.). We

223 then conducted some simulations to identify the number of candidate genes that would need to

224 be multiplexed to successfully target all individuals within the target species. This consisted in

225 searching the de novo assemblies (BLASTn e-value cutoff of 1e-20) with combination patterns

226 of one to ten candidate genes. For each pattern, 500 random combinations were generated and

227 tested.

228

229 Experimental screening. For each group of plant pathogens, we selected a subset of the

230 candidate genes identified by the pipeline. Candidate genes from different scaffolds were

231 selected to maximize the representation of genomic regions. Candidate genes were screened with

232 biological material to eliminate genes that failed to generate the expected amplicon in the

233 targeted species or generated amplicons in the most closely related species. Screening was

234 conducted by performing standard PCR using the selected primers and DNA of the target and the

235 most closely related species, followed by gel electrophoresis.

236 DNA was extracted from seventeen Dothideomycetes cultures representing 14

237 Capnodiales species, including five Septoria species closely related to $S$. musiva and $S$.

238 populicola (Feau et al., 2006). For testing the candidate genes obtained for $P$. ramorum and $P$.

239 lateralis, we used DNA extracted from 41 species distributed among nine phylogenetic clades

240 (out of the ten clades known; Martin et al., 2014), including 11 species from clade 8 which are

241 closely related to the two targeted species. This collection was reduced to 22 species for testing 
242 P. kernoviae-specific candidate genes, but included the other two species that are found in clade

$24310(P$. boehmeriae and $P$. gallica) with P. kernoviae. DNA from rust samples was obtained from

24419 Melampsora and 12 Cronartium and Endocronartium taxa and 18 species from three

245 additional Uredinales genera. For the Phytophthora and Dothideomycetes, 5 ng of DNA template

246 was used in the PCR reactions $\left(95^{\circ} \mathrm{C}\right.$ for $3 \mathrm{~min}, 29$ cycles of $95^{\circ} \mathrm{C}$ for $30 \mathrm{~s}, 62{ }^{\circ} \mathrm{C}$ for $30 \mathrm{~s}$ and

$24772{ }^{\circ} \mathrm{C}$ for $1 \mathrm{~min}$, and a final extension step of $72{ }^{\circ} \mathrm{C}$ for $10 \mathrm{~min}$ ) in a $25 \mu 1$ volume reaction mix

$248(10 \mu \mathrm{M}$ primer concentration and $0.2 \mu \mathrm{l}$ Platinum Taq DNA polymerase, Invitrogen, Life

249 Science Technologies, Carlsbad, CA). For the Pucciniales, primer concentration was at $1 \mathrm{uM}$ and

250 thermocycling conditions were slightly different : $94{ }^{\circ} \mathrm{C}$ for $3 \mathrm{~min}, 35$ cycles of $92{ }^{\circ} \mathrm{C}$ for $30 \mathrm{~s}$,

$25160{ }^{\circ} \mathrm{C}$ for $30 \mathrm{~s}$ and $72{ }^{\circ} \mathrm{C}$ for $1 \mathrm{~min}$, and a final extension step of $72{ }^{\circ} \mathrm{C}$ for $10 \mathrm{~min}$. PCR

252 amplification was assessed running $5 \mu 1$ of the PCR product in a 1.5-2\% agarose gel stained with

253 ethidium bromide.

254

255 Results

\section{Computational testing}

257 Filtering simulations. Simulations with BLASTn and BLASTp filtering conducted on a set of

25813 Phytophthora and 16 Dothideomycetes genomes suggested that the BLASTp e-value cutoff

259 had a positive impact in removing false positive candidates when the genome sequences used

260 were of poor quality (i.e. "fragmented genomes"; Text S1 "Filtering simulations with Module 3",

261 Fig. S1 and S2). When genomic distances between target and non-target taxa are short, rejection

262 of candidate by the BLASTn filter can rapidly increase with diminution of the e-value cutoff

263 (Fig. S3B). Use of stringent filters (i.e. high e-value cutoffs) rejected most of the potential false

264 positive candidates, in particular when the genomic distances between the target and non-target 
265 taxa were short i.e. when taxa were closely related (Text S1 "Filtering simulations with Module 266 3", Fig. S3).

267 Pipeline run on Phytophthora. Nine Phytophthora genomes were selected in Module 1 (Table

268 2; Feau et al., 2016). OrthoMCL search in Module 2 identified 52,280 clusters, including 1,624

269 (3.1\%) and 5,578 (10.7\%) putative unique clusters in P. ramorum and P. lateralis, respectively

270 (Table 2). The filtering step in Module 3 decreased the number of candidates to 37 for $P$.

271 ramorum and 180 for $P$. lateralis, suggesting that about $97 \%$ of the putative unique candidate

272 clusters predicted in the OrthoMCL analysis were false positives according to our filtering

273 criteria (Table 2). At a higher hierarchical level, the OrthoMCL search resulted in 110 clusters

274 that were shared between $P$. ramorum and $P$. lateralis and not found in the six other species;

275 nine $(0.02 \%)$ of these clusters were retained after the Module 3 filtering with default values. For

276 P. kernoviae, 830 putative unique clusters were identified out of 44,422 OrthoMCL clusters,

277 which were reduced to 55 candidates after Module 3 filtering.

278

279

280

281

282

283

284

285

286

287

Pipeline run on Dothideomycetes. Genomic resources for 13 Dothideomycete fungal species

were selected in Module 1 of the pipeline (Table 2). Statistics for the de novo genome assemblies were within the range of those obtained from public databases with N50 ranging from 0.06 to $0.18 \mathrm{Mb}$ and BUSCO completeness over $99.3 \%$ (Table S1). From 160,617 protein models, OrthoMCL generated 16,103 protein clusters and 28,086 singletons, with 885 and 765 unique clusters for $S$. musiva and $S$. populicola, respectively. This represents about $8.0 \%$ of the protein content predicted for these two genomes (Dhillon et al., 2015). Module 3 filtering reduced this number to 131 and 134 candidates for S. musiva and S. populicola, respectively. At higher hierarchical levels, analysis of poplar pathogens S. musiva, S. populicola and Mycosphaerella sp. STON1 resulted in 163 candidate clusters $(52.8 \%$ of the candidate clusters were eliminated) 
288 whereas for the two pathogens of the poplar section Aigeiros, S. musiva and S. populicola,

$28982.6 \%$ of the 392 candidate clusters were discarded. Adding three Dothideomycete genomes to 290 our initial collection before searching candidates for the Swiss needle cast fungus $P$. gaeumannii 291 increased the total number of clusters to $16,662(17 \%$ increase) and singletons $(34,586)$ found by 292 OrthoMCL (Table 2). Among these, 3350 (6.5\%) were unique in silico candidates for $P$. 293 gaeumannii and 1000 candidate clusters remained after Module 3 filtering.

294

295

296

297

298

299

300

301

302

303

304

305

306

307

308

309

310

Pipeline run on Pucciniales. In Module 1, a comprehensive proteome dataset from 17 rust species (including nine obtained in this project) was selected to identify candidates unique to the individual species within two rust fungi genera, Melampsora (M. larici-populina and $M$. medusae) and Cronartium (C. ribicola), and genes that are conserved at the genus level for these two groups. OrthoMCL clustering (Module 2) resulted in a similar proportion of candidate clusters in M. larici-populina (3,550 clusters; $26.6 \%$ of all clusters) and C. ribicola $(2,782$; $28.8 \%$ ) (Table 2). The number of unique clusters obtained for M. larici-populina was only $9 \%$ lower than what was obtained in a pairwise comparison with the wheat rust Puccinia graminis $\mathrm{f}$. sp. tritici (3,903 unique gene clusters) (Duplessis et al., 2011), suggesting that addition of new proteomes to the clustering analysis does not have a drastic impact on the number of speciesspecific clusters. A high proportion of unique clusters (about twice the number found in the other two rust species) was obtained for $M$. medusae f. sp. deltoidae, likely resulting from the high number of protein models predicted in the genome of this pathogen (Table 2). After filtering in Module 3 the number of unique genes was reduced to 1,519, 1,542 and 1,341 for M. laricipopulina, M. medusae f. sp. deltoidae and C. ribicola, respectively (Table 2). Filtering at the genus level resulted in only 270 candidate clusters shared between seven Melampsora species and 34 between the four Cronartium/Endocronartium species (Tables 2 and S3). Module 4 
311 rejected $73.3 \%$ to $76.4 \%$ (for Melampsora and Cronartium, respectively) of these candidates due

312 to the presence of interspecific polymorphisms preventing the design of primers and probes with

313 PRIMER3.

314 In silico screening for intra-taxa variation.

315 Twenty-one out of the 37 candidate genes (56.7\%) obtained for P. ramorum were successfully

316 retrieved in the 40 de novo assemblies tested for P. ramorum (Figure 3A). The observed level of

317 presence/absence of the candidate genes may be explained by polymorphism among the

318 divergent $P$. ramorum lineages. Simulations carried out on the de novo assemblies with random

319 combinations of one to nine of the 40 candidate genes indicated that a minimum of four

320 candidate genes have to be multiplexed to successfully target the expected amplicon in $99.99 \%$

321 of the P. ramorum individuals (Figure 3B). For S. musiva, $82 \%$ of the candidate genes were

322 found in all 16 de novo genome assemblies tested. For this taxon, simulations indicated that the

323 combination of three random candidate genes should be sufficient to successfully target all $S$.

324 musiva individuals (Figure 3C and D).

\section{Experimental screening}

327 For each targeted taxon or group studied, primer pairs for 5 to 65 candidate genes identified in

328 the pipeline were evaluated for specificity. Overall, $76(25.5 \%)$ candidate genes were validated

329 out of the 297 tested. Within each group, the proportion of retained candidate genes after wet lab

330 testing for specificity were in the same range $(22.6,28.0 \%$ and $33.3 \%$ for the Pucciniales,

331 Dothideomycetes and Phytophthora, respectively) and not significantly different from the overall

332 proportion of successful candidates $($ Chi-2 value $=1.76, P[3 \mathrm{df}]=0.62)($ Table 3$)($ Fig. S4 and

333 S5). Furthermore, the number of non-target species considered in each group for PCR-testing

334 (11-24 species for the Pucciniales, 11-14 species for the Dothideomycetes and 22-40 species for

335 Phytophthora; Table 3) did not impact this success rate, as suggested by the lack of correlation 
336 between these two variables $\left(\mathrm{R}^{2}=-0.06, P=0.55\right)$. Similarly, the quality of the de novo genome

337 assembly (genome N50-value; Tables S1-S3) used for the targeted taxa does not seem to impact

338 this success $\left(\mathrm{R}^{2}=-0.06, P=0.61\right)$.

We provide a proof-of-concept for using whole genome sequence comparisons to design detection and diagnostic assays at different hierarchical levels in taxonomically diverse groups of crop and tree pathogens. The 73 whole genome sequences generated in this project or obtained from public databases were parsed to discover genes that are either unique to individual taxa or shared at different hierarchical levels within groups of taxa. Our approach, comprising in silico design and in vitro validation steps, generated 85 assays designed to specifically target species or groups of related species belonging to the Phytophthoras, Dothideomycetes and Pucciniales. explore levels of variability among genomes, genes and taxa. With the expansion of the comparative genomics field and the development of tools such as Markov clustering (Li et al., 2003; Szilagyi and Szilagyi, 2014), pairwise BLASTp and BLASTn (Lin et al., 2010; Yang et al., 2013; Xu et al., 2015), identification of the "non-core genome", i.e. taxon-specific regions and genes, has become routine in computational genomics. Gene content-based differentiation between closely related taxa of filamentous microorganisms with different lifestyles and ecology was crucial to identify genomic factors underlying these traits and gain insights into the mechanism of genome evolution (Dhillon et al., 2015; Goodwin et al., 2011; Grandaubert et al, 2014; Plissonneau et al., 2016). We used a similar conceptual approach to identify taxon-specific 
357 genome regions and validated the hypothesis that these regions could serve as targets for the

358 development of molecular assays for taxa detection.

Most PCR assays for pathogen detection use genes that are conserved to allow for primer design but comprise polymorphisms which can be targeted for design of discriminant oligonucleotide probes or primers. However, there is a trade-off in the selection of genome regions between low intra-specific heterogeneity (to allow design of universal primers) and interspecific divergence (to allow taxa discrimination). The internal transcribed spacer region (ITS) of the nuclear ribosomal repeat unit is widely used for PCR assays as well as for taxa discrimination and in DNA barcoding and metabarcoding studies (Schoch et al., 2012). It has the advantages of providing a large database of sequences and occurring in multiple copies in genomes which enable the development of very sensitive detection assays. However, the ITS can be limited for discrimination of phylogenetically related species and specificity is often an issue (Gazis et al., 2011). In particular, ITS resolution for taxa separation in species-rich Ascomycota (e.g. genera Cladosporium, Penicillium and Fusarium) has often been inferior to several of the protein-coding genes commonly used in fungal taxonomy (Seifert 2009; Feau et al., 2011; Schoch et al., 2014; Vialle et al., 2009). Similarly, some of the taxa within the groups that were used in this study are closely related and not readily distinguishable in assay design using the ITS region. Only eight SNPs [98.0\% similarity] are found between the ITS sequences of S. musiva and $S$. populicola and six SNPs [99.03\% similarity] are present between the ITS sequences of $P$. ramorum and P. lateralis (Feau et al., 2005; Werres et al., 2001). In addition, sub-specific

377 lineages with different epidemiological and biological characteristics often have nearly identical 378 ITS sequences, complicating or preventing the design of reliable and robust taxon-specific 
379

380

381

382

384

385

386

387

388

389

390

391

392

393

394

395

396

397

398

399

400

401

assays. This is the case of the four lineages of $P$. ramorum that differ in mating types and aggressiveness yet share identical ITS sequences (Ivors et al., 2004; Eyre, 2014).

The method described herein provides benefits compared with assays conventionally designed on the basis of SNPs found in conserved genes among taxa. By focusing on taxonspecific genes for qPCR detection assays, we expected to lower type I errors, thereby maximizing specificity and reducing false positives. Despite its relative simplicity, our pipeline comprises several steps to limit both false positives and negatives. Filtering conducted in Module 3 greatly reduced the number of candidate genes by performing reciprocal blast searches across the genomes. This step was essential because of the variation in quality encountered in genome assembly and annotation. A second in vitro screening eliminated candidate genes that failed to amplify or discriminate close relatives. This two-step approach was efficient in quickly identifying potential unique and shared genes that are candidates for assay design and eliminating those that could yield false positives. It should be noted that the rate of conversion from in silico to in vitro validation steps $(\sim 28 \%)$ could be improved by fine-tuning the assay design and conducting additional in silico testing for intra-taxa variability using additional de novo assemblies in the targeted taxa. Moving or redesigning primers would make it possible to obtain amplicons for those candidate genes that failed the in silico validation step. However, since we obtained a large number of candidate genes for each taxonomic group targeted and our goal was to establish a proof-of-concept, we simply eliminated those that failed the in vitro screening step and we were still able to generate a large number of assays.

Another advantage of our approach is that primer design is less constrained since the genes targeted are unique, or at least they are not found in the genomes of phylogenetically related taxa. This could facilitate the design of multiplex qPCR assays that use internal probes 
402 with different fluorochromes within a single reaction. Development of multiplex assays requires

403 homogenization of annealing temperatures for the primers and probes targeting each amplicon.

404 This design should be more efficient since the primers and probes in the unique targeted genes

405 can be moved or their size can be customized without having the constraint of targeting

406 discriminant SNPs. In addition, targeting unique genes reduces the likelihood of cross-interaction

407 amongst the amplicons.

The conceptual and practical simplicity of qPCR, in combination with its speed and sensitivity, have made it the technology of choice in many diagnostic applications, including microbial quantification (Yu et al., 2005; Narihiro and Sekiguchi, 2011; Thonar et al., 2012) and pathogen detection (Orlofsky et al., 2015). Multiple qPCR assays have become extremely powerful to detect fungi, bacteria and parasites (Kamau et al., 2014; Gosiewski et al., 2014, Bilodeau et al., 2009) and we believe that this pipeline should enable development of qPCR assays in crop and tree pathogens. The pipeline described herein could be easily applied to any DNA-based detection methods (Yeo and Wong, 2002), such as loop-mediated isothermal amplification (LAMP), hybridization-based microarray (Huang et al., 2006) or PCR-ELISA

417 (Löffler et al., 1998). It would be particularly well-suited to target-enrichment methods by 418 providing a large number of relevant genomic regions that can be used to enrich pathogen target genes in environmental samples. We expect that the impact of our approach and its efficiency in developing taxon-specific targets will improve quickly with the steady increase in the number of whole fungal and oomycete genome sequences (Figure 2). 
425 clear demonstration that a genome-wide approach can be useful to efficiently identify multiple,

426 taxon-specific gene regions at different hierarchical levels that contain reliable priming site. We

427 successfully discovered a large number of unique genes even between closely related species

428 such as $P$. ramorum and $P$. lateralis $(99.0 \%$ similarity in the ITS) and $S$. musiva and $S$.

429 populicola $(98.0 \%$ similarity). This approach is therefore likely to be broadly applicable to other

430 fungi and Oomycetes. The possibility to easily obtain multiple alternative regions with equal or

431 improved performance to the ITS region and other universal protein-coding genes commonly

432 used for designing qPCR assays should be of great help in dealing with challenging cases for

433 which higher taxonomic resolution is needed, such as for hybrids and races. Heteroploid

434 organisms such as Phytophthora x alni (Aguayo et al, 2016) represent more complicated cases in

435 the development of qPCR diagnostic tools (e.g. Martin et al., 2012). Homology to the putative

436 parental species (Ioos et al., 2005; Inderbitzin et al., 2013) and deficiency of concerted

437 evolution in homogenizing intra-individual copies (Lindner et al., 2013) in the ITS region make

438 this marker often unsuitable for assay design in such organisms. Multiple taxon-specific assays

439 derived from whole genome sequences that target DNA inherited from the different lineages

440 should help to obtain reliable identification. Such challenges should likely be resolved with the

441 generation of good quality genomes based on long-read sequencing (Chin et al., 2013).

\section{Conclusions}

443 We developed a pipeline that makes use of the increasing availability of whole genome

444 sequences to identify unique taxon-discriminating genome regions as well as regions conserved

445 across taxa that can be converted into PCR assays. We applied this approach to some of the most

446 important plant pathogens and converted nearly one-third into qPCR assays. Our work

447 demonstrates that a genome-wide approach can efficiently identify multiple taxon-specific 
448

449

450

451

452

453

454

455

456

457

458

459

460

461

462

463

464

465

466

467

468

469

470

471

472

473

474

475

476

477

478

479

480

481

482

483

genome regions that can be converted into highly specific DNA detection and identification

assays.

\section{References}

Abbas MM, Malluhi QM, Balakrishnan P. 2014. Assessment of de novo assemblers for draft genomes: a case study with fungal genomes. BMC genomics 15:S10.

Aguayo J, Halkett F, Husson C, Nagy ZÁ, Szigethy A, Bakonyi J, Frey P, Marçais B. 2016. Genetic diversity and origins of the homoploid-type hybrid Phytophthora $\times$ alni. Applied and Environmental Microbiology 82:7142-7153.

Bilodeau, G, Pelletier G, Pelletier F, Levesque CA, Hamelin RC. 2009. Multiplex real-time polymerase chain reaction (PCR) for detection of Phytophthora ramorum, the causal agent of sudden oak death. Canadian Journal of Plant Pathology 31:195-210.

Blaecher C, Bauwens E, Tay A, Peters F, Dobbs S, Dobbs J, Charlett A, Ducatelle R, Haesebrouck F, Smet A. 2017. A novel isolation protocol and probe-based RT-PCR for diagnosis of gastric infections with the zoonotic pathogen Helicobacter suis. Helicobacter 22(3).

Botes M, de Kwaadsteniet M, Cloete TE. 2013. Application of quantitative PCR for the detection of microorganisms in water. Analytical and Bioanalytical Chemistry 405:91-108.

Brasier CM, Beales PA, Kirk SA, Denman S, Rose J. 2005. Phytophthora kernoviae sp. nov., an invasive pathogen causing bleeding stem lesions on forest trees and foliar necrosis of ornamentals in the UK. Mycological Research 109:853-859.

Brasier C, Webber J. 2010. Plant pathology: sudden larch death. Nature 466:824-825.

Bustin SA, Benes V, Garson JA, Hellemans, J, Huggett J, Kubista M, Mueller R, Nolan T, Pfaffl MW, Shipley GL, Vandesompele J, Wittwer CT. 2009. The MIQE guidelines: minimum information for publication of quantitative real-time PCR experiments. Clinical Chemistry 55:611-622.

Chin CS, Alexander DH, Marks P, Klammer AA, Drake J, Heiner C, Clum A, Copeland A, Huddleston J, Eichler EE, Turner SW. 2013. Nonhybrid, finished microbial genome assemblies from long-read SMRT sequencing data. Nature Methods 10:563-569.

DeAngelis KM, Pold G, Topçuoğlu BD, van Diepen LT, Varney RM, Blanchard JL, Melillo J, Frey SD. 2015. Long-term forest soil warming alters microbial communities in temperate forest soils. Frontiers in Microbiology 6:104.

Desprez-Loustau ML, Aguayo J, Dutech C, Hayden KJ, Husson C, Jakushkin B, Marçais B, Piou D, Robin C, Vacher C. 2016. An evolutionary ecology perspective to address forest pathology challenges of today and tomorrow. Annals of Forest Science 73:45-67. 
484

485

486

487

488

489

490

491

492

493

494

495

496

497

498

499

500

501

502

503

504

505

506

507

508

509

510

511

512

513

514

515

516

517

518

519

520

521

522

523

524

Deepak SA, Kottapalli KR, Rakwal R, Oros G, Rangappa KS, Iwahashi H, Masuo Y, Agrawal GK. 2007. Real-Time PCR: revolutionizing detection and expression analysis of genes. Current Genomics 8:234-251.

Dhillon B, Feau N, Aerts AL, Beauseigle S, Bernier L, Copeland A, Foster A, Gill N, Henrissat B, Herath P, LaButti KM, Levasseur A, Lindquist EA, Majoor E, Ohm RA, Pangilinan JL, Pribowo A, Saddler JN, Sakalidis ML, de Vries RP, Grigoriev IV, Goodwin SB, Tanguay P, Hamelin RC.. 2015. Horizontal gene transfer and gene dosage drives adaptation to wood colonization in a tree pathogen. Proceedings of the National Academy of Sciences of the United States of America 122:3451-3456.

Duplessis S, Cuomo C, Lin Y-C, Aerts A, Tisserant E, Veneault-Fourrey C, Joly DL, Hacquard S, Amselem J, Cantarel BL, Chiu R, Chiu R, Coutinho PM, Feau N, Field M, Frey P, Gelhaye E, Goldberg J, Grabherr MG, Kodira CD, Kohler A, Kües U, Lindquist EA, Lucas SM, Mago R, Mauceli E, Morin E, Murat C, Pangilinan JL, Park R, Pearson M, Quesneville H, Rouhier N, Sakthikumar S, Salamov AA, Schmutz J, Selles B, Shapiro H, Tanguay P, Tuskan GA, Henrissat B, Van de Peer Y, Rouzé P, Ellis JG, Dodds PN, Schein JE, Zhong S, Hamelin RC, Grigoriev IV, Szabo LJ, Martin F. 2011. Obligate biotrophy features unraveled by the genomic analysis of rust fungi. Proceedings of the National Academy of Sciences of the United States of America 108:9166-9171.

Elfving K, Andersson M, Msellem MI, Welinder-Olsson C, Petzold M, Björkman A, Trollfors B, Mårtensson A, Lindh M. 2014. Real-time PCR threshold cycle cutoffs help to identify agents causing acute childhood diarrhea in Zanzibar. Journal of Clinical Microbiology 52:916-923.

Eyre CA, Hayden KJ, Kozanitas M, Grunwald NJ, Garbelotto M. 2014. Lineage, temperature, and host species have interacting effects on lesion development in Phytophthora ramorum. Plant Disease 98:1717-1727.

Faino L, Thomma BPHJ, 2014. Get your high-quality low-cost genome sequence. Trends in Plant Science 19:288-291.

Farrington HL, Edwards CE, Guan X, Carr MR, Baerwaldt K, Lance RF. 2015. Mitochondrial genome sequencing and development of genetic markers for the detection of DNA of invasive bighead and silver carp (Hypophthalmichthys nobilis and H. molitrix) in environmental water samples from the United States. PLoS One 10:e0117803.

Feau N, Weiland JE, Stanosz GR, Bernier L. 2005. Specific and sensitive PCR-based detection of Septoria musiva, S. populicola and S. populi the causes of leaf spot and stem canker on poplars. Mycological Research 109:1015-1028.

Feau N, Hamelin RC, Bernier L. 2006. Attributes and congruence of three molecular data sets: Inferring phylogenies among Septoria-related species from woody perennial plants. Molecular Phylogenetics and Evolution 40:808-829.

Feau N, Mottet MJ, Périnet P, Hamelin RC, Bernier L. 2010. Recent advances related to poplar leaf spot and canker caused by Septoria musiva. Canadian Journal of Plant Pathology 32:122-134. 
Feau N, Taylor G, Dale AL, Dhillon B, Bilodeau GJ, Birol I, Jones SJM, Hamelin RC. 2016. Genome sequences of six Phytophthora species threatening forest ecosystems. Genomics Data 10:85-88.

Firth C, Lipkin WI. 2013. The genomics of emerging Pathogens. Annual Review of Genomics and Human Genetics 4:281-300.

Fisher MC, Henk DA, Briggs CJ, Brownstein JS, Madoff LC, McCraw SL, Gurr SJ. 2012. Emerging fungal threats to animal, plant and ecosystem health. Nature 484:186-194.

Higuchi R, Fockler C, Dollinger G, Watson R. 1993. Kinetic PCR analysis: real-time monitoring of DNA amplification reactions. Nature Biotechnology 11:1026-1030.

Gallo JE, Muñoz JF, Misas E, McEwen JG, Clay OK. 2014. The complex task of choosing a de novo assembly: lessons from fungal genomes. Computational Biology and Chemistry 53:97-107.

Gazis R, Rehner S, Chaverri P. 2011. Species delimitation in fungal endophyte diversity studies and its implications in ecological and biogeographic inferences. Molecular Ecology 20:3001-3013.

Gosiewski T, Jurkiewicz-Badacz D, Sroka A, Brzychczy-Włoch M, Bulanda, M. 2014. A novel, nested, multiplex, real-time PCR for detection of bacteria and fungi in blood. $B M C$ Microbiology 14:144.

Grandaubert J, Lowe RGT, Soyer JL, Schoch CL, de Wouw AP, Fudal I, Robbertse B, Lapalu N, Links MG, Ollivier B, Linglin J, Barbe V, Mangenot S, Cruaud C, Borhan H, Howlett BJ, Balesdent M-H, Rouxel T. 2014. Transposable element-assisted evolution and adaptation to host plant within the Leptosphaeria maculans-Leptosphaeria biglobosa species complex of fungal pathogens. BMC Genomics 15:891.

Hansen EM, Goheen DJ, Jules ES, Ullian B. 2000. Managing Port-Orford-cedar and the introduced pathogen Phytophthora lateralis. Plant Disease 84:4-14.

Haridas S, Breuil C, Bohlmann J, Hsiang T. 2011. A biologist's guide to de novo genome assembly using next-generation sequence data: a test with fungal genomes. Journal of Microbiological Methods 86:368-375.

Ho CC, Lau CC, Martelli P, Chan SY, Cindy WS, Wu AK, Yuen KY, Lau SK, Woo PC. 2011. Novel pan-genomic analysis approach in target selection for multiplex PCR identification and detection of Burkholderia pseudomallei, Burkholderia thailandensis, and Burkholderia cepacia complex species: a proof-of-concept study. Journal of Clinical Microbiology 49:814-821.

Ho CC, Wu AK, Cindy WS, Yuen KY, Lau SK, Woo PC. 2012. Automated pangenomic analysis in target selection for PCR detection and identification of bacteria by use of ssGeneFinder webserver and its application to Salmonella enterica serovar typhi. Journal of Clinical Microbiology 50:1905-1911.

Haas BJ, Zeng Q, Matthew D. Pearson MD, Cuomo CA, Wortman JR. 2011. Approaches to fungal genome annotation. Mycology 2:118-141.

Hänsel C, Mertens K, Elschner MC, Melzer F. 2015. Novel real-time PCR detection assay for Brucella suis. Veterinary Record Open 2:e000084. 
566

567

568

569

570

571

572

573

574

575

576

577

578

579

580

581

582

583

584

585

586

587

588

589

590

591

592

593

594

595

596

597

598

599

600

601

602

603

604

605

606

Heid CA, Stevens J, Livak KJ, Williams PM. 1996. Real time quantitative PCR. Genome research 6:986-994.

Hellemans J, Mortier G, De Paepe A, Speleman F, Vandesompele J. 2007. qBase relative quantification framework and software for management and automated analysis of real-time quantitative PCR data. Genome Biology 8:R19.

Henson JM. 1989. DNA probe for identification of the take-all fungus, Gaeumannomyces graminis. Applied Environmental Microbiology 55:284-288.

Holland PM, Abramson RD, Watson R, Gelfand DH. 1991. Detection of specific polymerase chain reaction product by utilizing the 5'----3' exonuclease activity of Thermus aquaticus DNA polymerase. Proceedings of the National Academy of Sciences of the United States of America 88:7276-7280.

Huang A, Li JW, Shen ZQ, Wang XW, Jin M. 2006. High-throughput identification of clinical pathogenic fungi by hybridization to an oligonucleotide microarray. Journal of Clinical Microbiology, 44:3299-3305.

Inderbitzin P, Davis RM, Bostock RM, Subbarao KV. 2013. Identification and differentiation of Verticillium species and $V$. longisporum lineages by simplex and multiplex PCR assays. PLoS ONE 8:e65990.

Ioos R, Husson C, Andrieux A, Frey P. 2005. SCAR--based PCR primers to detect the hybrid pathogen Phytophthora alni and its subspecies causing alder disease in Europe. European Journal of Plant Pathology 112:323-335.

Ioos R, Fabre B, Saurat C, Fourrier C, Frey P, Marçais B. 2009. Development, comparison, and validation of real-time and conventional PCR tools for the detection of the fungal pathogens causing brown spot and red band needle blights of pine. Phytopathology 100:105-114.

Ivors KL, Hayden KJ, Bonants PJM, Rizzo DM, Garbelotto M. 2004. AFLP and phylogenetic analyses of North American and European populations of Phytophthora ramorum. Mycological Research 108:378-392.

Kamau E, Alemayehu S, Feghali KC, Juma DW, Blackstone GM, Marion WR, Obare P, Ogutu B, Ockenhouse CF. 2014. Sample-ready multiplex qPCR assay for detection of malaria. Malaria Journal 13:158.

Klein, D. 2002. Quantification using real-time PCR technology: applications and limitations. Trends in Molecular Medecine 8:257-260.

Kroon LP, Bakker FT, van den Bosch GB, Bonants PJ, Flier WG. 2004. Phylogenetic analysis of Phytophthora species based on mitochondrial and nuclear DNA sequences. Fungal Genetics and Biology 41:766-782.

Lamarche J, Potvin A, Pelletier G, Stewart D, Feau N, Alayon DIO, Dale AL, Coelho A, Uzunovic A, Bilodeau GJ, Brière SC, Hamelin RC, Tanguay P. 2015. Molecular detection of 10 of the most unwanted alien forest pathogens in Canada using real-time PCR. PLoS One 10:e134265.

Li L, Stoeckert CJ, Roos DS. 2003. OrthoMCL: Identification of ortholog groups for eukaryotic genomes. Genome Research 13:2178-2189. 
607

608

609

610

611

612

613

614

615

616

617

618

619

620

621

622

623

624

625

626

627

628

629

630

631

632

633

634

635

636

637

638

639

640

641

642

643

644

645

646

Lin H, Moghe G, Ouyang S, Iezzoni A, Shiu S-H, Gu X, Buell CR. 2010. Comparative analyses reveal distinct sets of lineage-specific genes within Arabidopsis thaliana. BMC Evolutionary Biology 10:41.

Liu CM, Kachur S, Dwan MG, Abraham AG, Aziz M, Hsueh PR, Huang YT, Busch JD, Lamit LJ, Gehring CA, Keim P. 2012. FungiQuant: a broad-coverage fungal quantitative real-time PCR assay. BMC Microbiology 12:255.

Lindner, DL, Carlsen, T, Henrik Nilsson, R, Davey, M, Schumacher, T, Kauserud, H. 2013. Employing 454 amplicon pyrosequencing to reveal intragenomic divergence in the internal transcribed spacer rDNA region in fungi. Ecology and Evolution 3:1751-1764.

Liu J, Gratz J, Amour C, Kibiki G, Becker S, Janaki L, Verweij JJ, Taniuchi M, Sobuz SU, Haque R, Haverstick DM. 2013. A laboratory-developed TaqMan array card for simultaneous detection of 19 enteropathogens. Journal of Clinical Microbiology 51:472480.

Loeffler, J, Hebart, H, Sepe, S, Schumacher, U, Klingebiel, T, Einsele, H. 1998. Detection of PCR-amplified fungal DNA by using a PCR-ELISA system. Medical Mycology, 36:275279.

Ma L-J, D. Fedorova ND. 2010. A practical guide to fungal genome projects: strategy, technology, cost and completion. Mycology 1:9-24.

Martin FN, Blair JE, Coffey MD. 2014. A combined mitochondrial and nuclear multilocus phylogeny of the genus Phytophthora. Fungal Genetics and Biology 66:19-32.

Martin FN, Z. Abad ZG, Balci Y, Ivors K. 2012. Identification and detection of Phytophthora: Reviewing our progress, identifying our needs. Plant Disease 96:1080-1103

Martin FN, Coffey MD, Zeller K, Hamelin RC, Tooley P, Garbelotto M, Hughes KJD,

Kubisiak T, Bilodeau GJ, Levy L, Blomquist C, Berger PH. 2009. Evaluation of Molecular markers for Phytophthora ramorum detection and identification: Testing for specificity using a standardized library of isolates. Phytopathology 99:390-403.

Martin, RR, James, D, Lévesque, CA. 2000. Impacts of molecular diagnostic technologies on plant disease management. Annual Review of Phytopathology 38:207-239.

McCartney HA, Foster SJ, Fraaije BA, Ward E. 2003. Molecular diagnostics for fungal plant pathogens. Pest Management Science 59:129-142.

Monis PT, Giglio S. 2006. Nucleic acid amplification-based techniques for pathogen detection and identification. Infection, Genetics and Evolution 6:2-12.

Mutasa ES, Ward E, Adams MJ, Collier CR, Chwarszczynska DM, Asher MJ. 1993. A sensitive DNA probe for the detection of Polymyxa betae in sugar beet roots. Physiological and Molecular Plant Pathology 43:379-390.

Narihiro, T., Sekiguchi, Y. 2011. Oligonucleotide primers, probes and molecular methods for the environmental monitoring of methanogenic archaea. Microbiology and Biotechnology 4:585-604.

Nehme, B, Létourneau, V, Forster, RJ, Veillette, M, Duchaine, C. 2008. Cultureindependent approach of the bacterial bioaerosol diversity in the standard swine 
647

confinement buildings, and assessment of the seasonal effect. Environmental Microbiology 10:665-675.

Nilsson, RH, Kristiansson, E, Ryberg, M, Hallenberg, N, Larsson, KH. 2008. Intraspecific ITS variability in the kingdom Fungi as expressed in the international sequence databases and its implications for molecular species identification. Evolutionary Bioinformatics Online 4:193-201.

Nutz S, Döll K, Karlovsky P. 2011. Determination of the LOQ in real-time PCR by receiver operating characteristic curve analysis: application to qPCR assays for Fusarium verticillioides and F. proliferatum. Analytical and Bioanalytical Chemistry 401:717-726.

Orlofsky, E, Benami, M, Gross, A, Dutt, M, Gillor, O. 2015. Rapid MPN-Qpcr screening for pathogens in air, soil, water, and agricultural produce. Water, Air, Soil Pollution 226:303.

Pautasso M, Schlegel M, Holdenrieder O. 2015. Forest health in a changing world. Microbial Ecology 69:826-842.

Patrinos, GP, Ansorge, W. 2010. Molecular diagnostics. Elsevier, Amsterdam.

Plissonneau C, Stürchler A, Croll D. 2016. The evolution of orphan regions in genomes of a fungal pathogen of wheat. mBio 7:5e01231-16

Prévost-Bouré, NC, Christen, R, Dequiedt, S, Mougel, C, Lelièvre, M, Jolivet, C, Shahbazkia HR, Guillou L, Arrouays D, Ranjard L. 2011. Validation and application of a PCR primer set to quantify fungal communities in the soil environment by real-time quantitative PCR. PLoS One 6:e24166.

Rachwal PA, Rose HL, Cox V, Lukaszewski RA, Murch AL, Weller SA. 2012. The potential of TaqMan array cards for detection of multiple biological agents by real-time PCR. PLoS One 7:e35971.

Robideau GP, De Cock AW, Coffey MD, Voglmayr H, Brouwer H, Bala K, Chitty DW, Désaulniers N, Eggertson QA, Gachon CM, Hu CH, Küpper FC, Rintoul TL, Sarhan E, Verstappen EC, Zhang Y, Bonants PJ, Ristaino JB, Lévesque CA. 2011. DNA barcoding of oomycetes with cytochrome $c$ oxidase subunit I and internal transcribed spacer. Molecular Ecology Resources 11:1002-1011.

Rozen S, Skaletsky H. 1999. Primer3 on the WWW for general users and for biologist programmers. Bioinformatics Methods and Protocols, pp.365-386.

Santini A, Ghelardini L, De Pace C, Desprez-Loustau ML, Capretti P, Chandelier A, Cech T, Chira D, Diamandis S, Gaitniekis T, Hantula J, Holdenrieder O, Jankovsky L, Jung T, Jurc D, Kirisits T, Kunca A, Lygis V, Malecka M, Marcais B, Schmitz S, Schumacher J, Solheim H, Solla A, Szabò I, Tsopelas P, Vannini A,Vettraino AM, Webber J, Woodward S, Stenlid J. 2013. Biogeographical patterns and determinants of invasion by forest pathogens in Europe. New Phytologist 197:238-250.

Schaad NW, Frederick RD. 2002. Real-time PCR and its application for rapid plant disease diagnostics. Canadian Journal of Plant Pathology 24:250-258.

Schardl,CL, Craven,KD. 2003. Interspecific hybridization in plant-associated fungi and oomycetes: a review. Molecular Ecology 12:2861-2873. 
687

688

689

690

691

692

693

694

695

696

697

698

699

700

701

702

703

704

705

706

707

708

709

710

711

712

713

714

715

716

717

718

719

720

721

722

723

724

725

726

Schena L, Li Destri Nicosia MG, Sanzani SM, Faedda R, Ippolito A, Cacciola SO. 2013. Development of quantitative PCR detection methods for phytopathogenic fungi and oomycetes. Journal of Plant Pathology 1:7-24.

Schoch CL, Seifert KA, Huhndorf S, Robert V, Spouge JL, Levesque CA, Chen W; Fungal Barcoding Consortium; Fungal Barcoding Consortium Author List.. 2012. Nuclear ribosomal internal transcribed spacer (ITS) region as a universal DNA barcode marker for Fungi. Proceedings of the National Academy of Sciences of the United States of America 109:6241-6246.

Seifert KA. 2009. Progress towards DNA barcoding of fungi. Molecular Ecology Resources 9:83-89.

Szilagyi SM, Szilagyi L. 2014. A fast hierarchical clustering algorithm for large-scale protein sequence data sets. Computational Biology and Medecine 48:94-101.

Smith, CJ, Osborn, AM. 2009. Advantages and limitations of quantitative PCR (Q-PCR)based approaches in microbial ecology. FEMS Microbiology and Ecology 67:6-20.

Stanke M, Schoffmann O, Morgenstern B, Waack S. 2006. Gene prediction in eukaryotes with a generalized hidden Markov model that uses hints from external sources. $B M C$ Bioinformatics 7:62

Thonar C, Erb A, Jansa, J. 2012. Real-time PCR to quantify composition of arbuscular mycorrhizal fungal communities - marker design, verification, calibration and field validation. Molecular Ecolology Resources 12: 219-232.

Vialle A, Feau N, Allaire M, Didukh M, Martin F, Moncalvo J-M, Hamelin RC. 2009. Evaluation of mitochondrial genes as DNA barcode for Basidiomycota. Molecular Ecology Resources 9:99-113.

Wang J, Jacobs JL, Byrne JM, Chilvers MI. 2015. Improved diagnoses and quantification of Fusarium virguliforme, causal agent of soybean sudden death syndrome. Phytopathology 105:378-87.

Waterman, AM. 1946. Canker of hybrid poplar clones in the United States, caused by Septoria musiva. Phytopathology 35:148-156.

Werres S, Marwitz R, Man in't Veld WA, de Cock AWAM, Bonants PJM, de Weerdt M, Themanna K, Ilieva E, P.Baayen RP. 2001. Phytophthora ramorum sp. nov., a new pathogen on Rhododendron and Viburnum. Mycological Research 105:1155-1165.

White JT, Bruns T, Lee S, Taylor J. 1990. Amplification and direct sequencing of fungal ribosomal RNA genes for phylogenetics. In, Innis,M., Gelfand,D., Snisky,J., and White,T.J. (eds), PCR protocols: A guide to methods and applications. Academic Press, San Diego, California, pp. 315-322.

Wittwer CT, Herrmann MG, Moss AA, Rasmussen RP. 1997. Continuous fluorescence monitoring of rapid cycle DNA amplification. Biotechniques 22:130-138.

Xu Y, Wu G, Hao B, Chen L, Deng X, Xu Q. 2015. Identification, characterization and expression analysis of lineage-specific genes within sweet orange (Citrus sinensis). BMC Genomics 16:995. 
727 Yang L, Zou M, Fu B, He S. 2013. Genome-wide identification, characterization, and expression analysis of lineage-specific genes within zebrafish. BMC Genomics 14:65.

Yarwood SA, Bottomley PJ,Myrold DD. 2010. Soil microbial communities associated with Douglas-fir and red alder stands at high- and low-productivity forest sites in Oregon, USA. Microbial Ecology 60:606-617.

Yeo SF, Wong B. 2002. Current status of nonculture methods for diagnosis of invasive fungal infections. Clinical Microbiology Reviews 15:465-484.

Yu Y, Lee C, Kim J, Hwang S. 2005. Group-specific primer and probe sets to detect 


\section{Figure Legends}

740 Figure 1. Pipeline for development of qPCR assays using whole genomes

741 Figure 2. Number and phylogenic coverage of fungal (A) and Oomycete (B) genomes available

742 on the NCBI public database accessed on Feb., 6th2017

743 Figure 3. In silico screening for intra-taxon variation in Phytophthora ramorum (A and B) and

744 Sphaerulina musiva (C and D). Number of candidate genes predicted for P. ramorum $(\mathrm{n}=37)$ and

745 S. musiva $(\mathrm{n}=134)$ that targeted different proportions of the de novo genome assemblies of $P$.

746 ramorum $(\mathrm{n}=40)(\mathrm{A})$ and $S$. musiva $(\mathrm{n}=16)(\mathrm{C})$. Minimum number of candidate gene required to

747 successfully target all the de novo assemblies of P. ramorum (B) and S. musiva (C) 
Figure 1 (on next page)

Pipeline for development of qPCR assays using whole genomes 
Close relatives

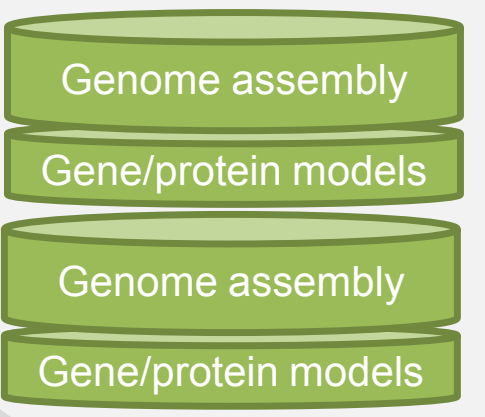

Download from public databases

OR

Genome sequencing

De novo assembly

(Abyss)

Prediction of models (Augustus)

Putative unique genes in target species

\section{Clustering (OrthoMCL)}

\section{Putative conserved} genes in target group

\section{Filtering}

BLASTn on non-target genomes BLASTp on non-target proteomes

Set of unique speciesspecific genes
Set of conserved group-specific genes
qPCR assay design

(PRIMER3) 
Figure 2

Number and phylogenic coverage of fungal $(A)$ and Oomycete $(B)$ genomes available on the NCBI public database 


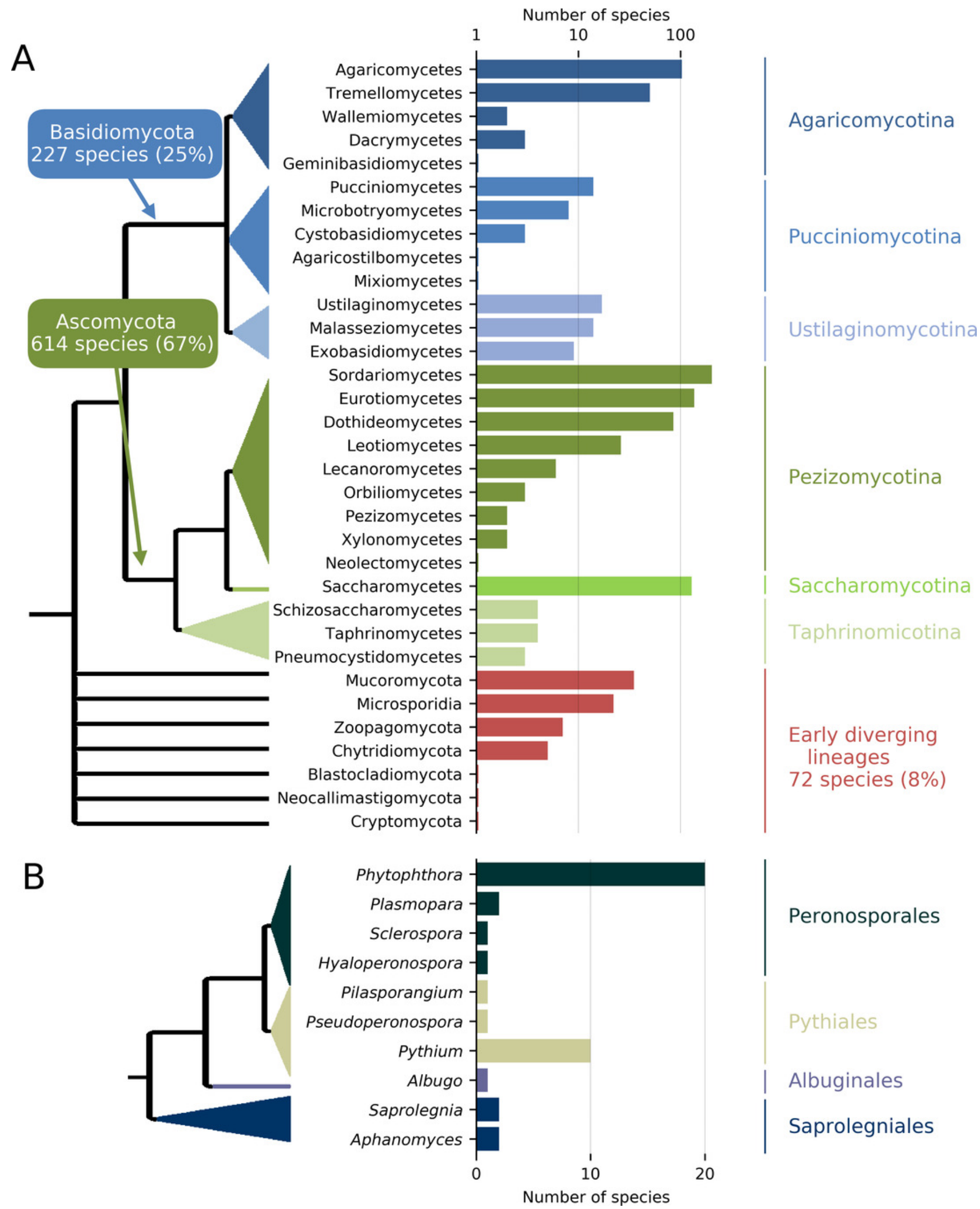


Figure 3

In silico screening for intra-taxon variation in Phytophthora ramorum (A and $\mathrm{B}$ ) and Sphaerulina musiva (C and D).

Number of candidate genes predicted for $P$. ramorum $(n=37)$ and S. musiva $(n=134)$ that targeted different proportions of the de novo genome assemblies of $P$. ramorum $(n=40)(A)$ and S. musiva $(n=16)(C)$. Minimum number of candidate gene required to successfully target all the de novo assemblies of $P$. ramorum (B) and $S$. musiva (C)

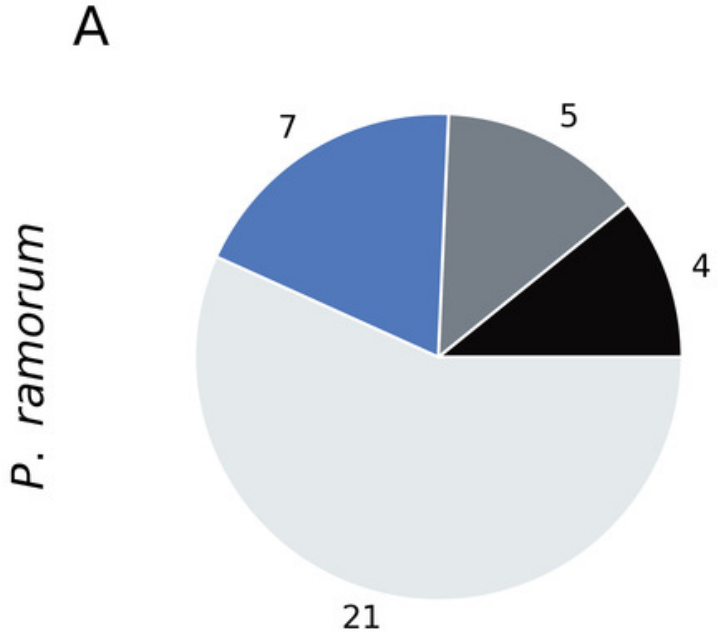

$\%$ of de novo assemblies successfully targeted:

$65-74 \%$
$75-89 \%$

C

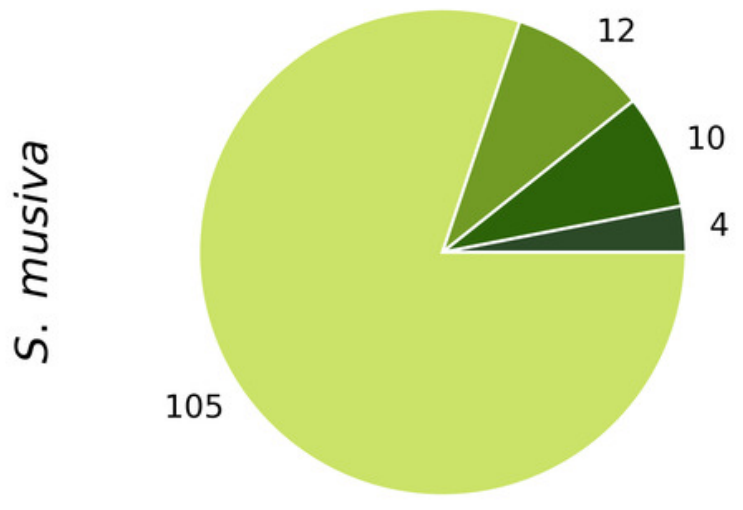

$\%$ of de novo assemblies successfully targeted :
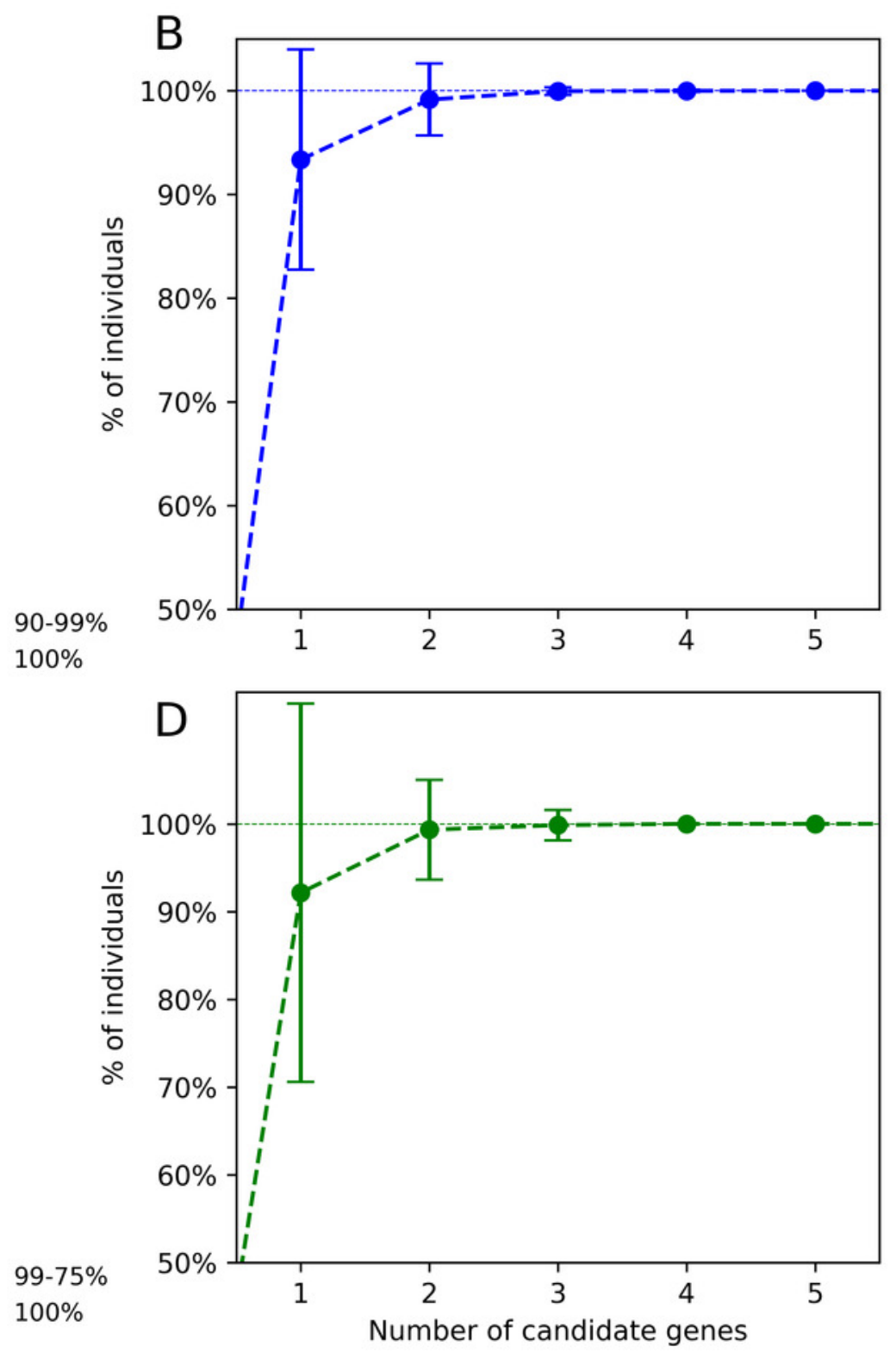


\section{Table $\mathbf{1}$ (on next page)}

Oligonucleotide primer and probes default parameters used in QPCR automated assay design (Module 4). 
Table 1. Oligonucleotide primer and probes default parameters used in qPCR automated assay design (Module 4).

\begin{tabular}{lccc}
\hline & Optimal & Range & Other \\
\hline Amplicon size & - & $80-150 \mathrm{bp}$ & - \\
\hline Primers & & & \\
\hline Length & $20 \mathrm{nt}$ & $18-24 \mathrm{nt}$ & - \\
Melting temperature (Tm) & $60^{\circ} \mathrm{C}$ & $60-63^{\circ} \mathrm{C}$ & - \\
GC\% & - & $50-60 \%$ & - \\
Maximum Tm difference between primers & 1.0 & - & - \\
Maximum 3' self-complementary & 1.0 & - & - \\
Maximum poly X & 3.0 & - & - \\
3'-end & & - & No G or C \\
\hline Hybridization probe & & & \\
\hline Length & - & $18-30 \mathrm{nt}$ & - \\
Melting temperature (Tm) & - & $65-70^{\circ} \mathrm{C}$ & - \\
GC\% & - & $45-65 \%$ & - \\
maximum poly X & 3.0 & - & - \\
5'-end & - & - & No G or C \\
\hline
\end{tabular}




\section{Table 2 (on next page)}

Number of species and genus-specific protein models found after clustering with OrthoMCL and filtering with BLASTn 
Table 2. Number of species and genus-specific protein models found after clustering with OrthoMCL and filtering with BLASTn

\begin{tabular}{|c|c|c|c|c|c|}
\hline \multirow[b]{2}{*}{ Targets } & \multicolumn{2}{|l|}{ Module 1} & \multicolumn{2}{|l|}{ Module 2} & \multirow{2}{*}{$\begin{array}{l}\text { Module } 3 \\
\text { \# of unique } \\
\text { clusters }\end{array}$} \\
\hline & Non-target genomes & $\begin{array}{l}\text { \# of } \\
\text { protein } \\
\text { models }\end{array}$ & $\begin{array}{l}\# \\
\text { OrthoMCL } \\
\text { clusters } \\
\end{array}$ & $\begin{array}{l}\text { \# OrthoMCL } \\
\text { unique } \\
\text { clusters }\end{array}$ & \\
\hline \multicolumn{6}{|l|}{ Phytophthora } \\
\hline \multicolumn{6}{|l|}{ Species-specific } \\
\hline P. ramorum & $\mathrm{PINF}^{1}, \mathrm{PSOJ}, \mathrm{PLAT}, \mathrm{PCAP}, \mathrm{PCIN}, \mathrm{PHIB}, \mathrm{PFOL}$ & & $52,280^{2}$ & 1624 (3.1\%) & 37 \\
\hline P. lateralis & PINF, PSOJ, PRAM, PCAP, PCIN, PHIB, PFOL & & $52,280^{2}$ & $5578(10.7 \%)$ & 180 \\
\hline P. kernoviae & PINF, PSOJ, PRAM, PCAP, PCIN & & 44,422 & $830(1.9 \%)$ & 55 \\
\hline \multicolumn{6}{|l|}{ Group-specific } \\
\hline P. ramorum + P. lateralis & PINF, PSOJ, PCAP, PCIN, PHIB, PFOL & & 52,280 & $110(0.2 \%)$ & 9 \\
\hline \multicolumn{6}{|l|}{ Dothideomycetes } \\
\hline \multicolumn{6}{|l|}{ Species-specific } \\
\hline Sphaerulina musiva & $\begin{array}{l}\text { STON, SPOP, MPUN, PGAE, MGRAM, MLAR, } \\
\text { MGIB, DPIN, DOTS, MDEAR, CLAF, MFIJ }\end{array}$ & 160,617 & $44,189^{2}$ & $885(2.0 \%)$ & 131 \\
\hline S. populicola & $\begin{array}{l}\text { STON, SMUS, MPUN, PGAE, MGRAM, MLAR, } \\
\text { MGIB, DPIN, DOTS, MDEAR, CLAF, MFIJ }\end{array}$ & 160,617 & $44,189^{2}$ & $765(1.7 \%)$ & 134 \\
\hline Phaeocryptopus gaeumannii & $\begin{array}{l}\text { STON, SMUS, SPOP, MPUN, MGRAM, MLAR, } \\
\text { MGIB, DPIN, DOTS, MDEAR, CLAF, MFIJ, CERZ, } \\
\text { BAUCO, DIDZE }\end{array}$ & 193,449 & $51,248^{2}$ & $3350(6.5 \%)$ & 1000 \\
\hline \multicolumn{6}{|l|}{ Group-specific } \\
\hline S. musiva + S. populicola & $\begin{array}{l}\text { STON, MPUN, PGAE, MGRAM, MLAR, MGIB, } \\
\text { DPIN, DOTS, MDEAR, CLAF, MFIJ }\end{array}$ & 160,617 & 44,189 & $392(0.9 \%)$ & 68 \\
\hline $\begin{array}{l}\text { S. musiva + S. populicola }+ \\
\text { STON1 }\end{array}$ & $\begin{array}{l}\text { STON, MPUN, PGAE, MGRAM, MLAR, MGIB, } \\
\text { DPIN, DOTS, MDEAR, CLAF, MFIJ }\end{array}$ & 160,617 & 44,189 & $345(0.8 \%)$ & 163 \\
\hline \multicolumn{6}{|l|}{ Rusts } \\
\hline \multicolumn{6}{|l|}{ Species-specific } \\
\hline Melampsora larici-populina & $\begin{array}{l}\text { All Pucciniales genomes in Table S3, but } M \text {. } \\
\text { larici-populina }\end{array}$ & & $13,355^{2}$ & $3550(26.6 \%)$ & 1519 \\
\hline M. medusae f. sp. deltoidae & $\begin{array}{l}\text { All Pucciniales genomes in Table } \mathrm{S} 3 \text {, but } M \text {. } \\
\text { medusae f. sp. deltoidae }\end{array}$ & & $20,713^{2}$ & 8901 (43.9\%) & 1542 \\
\hline
\end{tabular}


Cronartium ribicola All Pucciniales genomes in Table S3, but $C$. $9633^{2}$

Genus-specific ribicola

Melampsora genus

$1870^{3}$

$1027^{3}$

$374(20.0 \%)$

270

Cronartium genus

All Pucciniales genomes in Table S3, but

Melampsora spp.

All Pucciniales genomes in Table S3, but

Cronartium spp.

${ }^{1}$ Species name abbreviations : PINF, Phytophthora infestans; PSOJ, P. sojae; PCAP, P. capsicii; PCIN, P. cinnamomi var. cinnamomi; PHIB, P. hibernalis; PFOL, P. foliorum; PRAM, P. ramorum; PLAT, P. lateralis; STON, Mycosphaerella sp. STON; SMUS, Sphaerulina musiva, SPOP, S. populicola, PGAE, Phaeocryptopus gaeumannii; MPUN, Ramularia endophylla, MGRAM, Zymoseptoria tritici; MLAR, M. laricina; MGIB, Pseudocercospora pini-densiflorae; DPIN, Dothistroma pini; DOTS, D. septosporum; MDEAR, Lecanostica acicula; CLAF, Cladosporum fulvum; MFIJ, M. fijiensis; CERZ, C. zeae-maydis; BAUCO, Baudoinia compniacensis ; DIDZE, Didymella zeae-maydi.

${ }^{2}$ Number of OrthoMCL clusters that include at least one gene from the targeted species.

${ }^{3}$ Number of OrthoMCL clusters that include at least one gene for each species of the genus. 
Table 3 (on next page)

Experimental screening of the candidate clusters unique to species or group of taxa. 
Table 3. Experimental screening of the candidate clusters unique to species or group of taxa.

\begin{tabular}{|c|c|c|c|c|}
\hline Targeted taxa & $\begin{array}{c}\text { \# tested targeted } \\
\text { taxa }\end{array}$ & $\begin{array}{c}\text { \# tested non-targeted } \\
\text { taxa }\end{array}$ & $\begin{array}{l}\text { \# candidate } \\
\text { genes tested }\end{array}$ & \# success \\
\hline \multicolumn{5}{|l|}{ Phytophthora } \\
\hline P. ramorum & 11 P. ramorum & 40 Phytophthora spp. & 28 & $5(17.9 \%)$ \\
\hline P. lateralis & 4 P. lateralis & 40 Phytophthora spp. & 16 & $6(37.5 \%)$ \\
\hline P. kernoviae & $1 P$. kernoviae & 22 Phytophthora spp. & 12 & $9(75.0 \%)$ \\
\hline$P$. ramorum $+P$. lateralis & $11 P$. ramorum, 4 P. lateralis & 39 Phytophthora spp. & 19 & $5(26.3 \%)$ \\
\hline
\end{tabular}

Dothideomycetes

Sphaerulina musiva

S. populicola

Phaeocryptopus gaeumannii

S. musiva + S. populicola

S. musiva + S. populicola +

Mycosphaerella sp. STON1

\section{S. musiva}

2 S. populicola

10 P. gaeumannii

2. S. musiva, 2 S. populicola

2. S. musiva, 2 S. populicola,

1 Mycosphaerella sp. STON1
14 Mycosphaerella spp.

14 Mycosphaerella spp.

14 Mycosphaerella spp.

12 Mycosphaerella spp.

11 Mycosphaerella spp.
$14(27.5 \%)$

$16(24.6 \%)$

$3(30 \%)$

$13(33.3 \%)$

2 (33.3\%)

Rusts

Melampsora larici-populina

13 M. larici-populina

M. medusae f. sp. deltoidae

10 M. medusae

Cronartium ribicola

10 C. ribicola

Melampsora genus

Cronartium genus
19 Melampsora spp.

11 Cronartium spp.
15 Melampsora spp., 1 Coleosporium sp., 1

Pucciniastrum sp., 1 Cronartium sp., 2 Chrysomyxa

10

$2(20 \%)$

spp.

15 Melampsora spp., 1 Coleosporium sp., 1

Pucciniastrum sp., 1 Cronartium sp., 2 Chrysomyxa

10

spp.

10 Cronartium spp., 5 Melampsora spp., 3

Coleosporium spp., 3 Pucciniastrum spp., 2

Chrysomyxa spp.

2 Coleosporium spp., 3 Pucciniastrum spp., 3

Cronartium spp., 3 Chrysomyxa spp.

5

$3(60 \%)$

8 Melampsora spp., 4 Coleosporium spp., 5 Pucciniastrum spp., 7 Chrysomyxa spp. 


\section{PeerJ}

